\title{
THE SURVEY OF ENGLISH TEXTBOOKS USED IN FEMALE SCHOOLS IN BUKOVYNA (1900 - 1918)
}

\author{
Oksana Tumak \\ Chernivtsi National University, Chernivtsi, Ukraine \\ oksanatumak@gmail.com
}

\begin{abstract}
The given article presents a survey of the English textbooks which were used at the lessons of English in female schools of Bukovyna in the beginning of the XX century. The author gives an overview of reference sources relevant to the issue under discussion and proves that the studied topic had not been in the focus of the scientific research before. The analysis of the textbooks was made using formal, functional, structural and subjective criteria. We reviewed 5 English textbooks, found in the scientific library and identified the English language teaching methods used in these books. The textbooks were divided into 3 groups: grammar references, textbooks and readers. The characteristic feature of the textbooks is that they were written in German, thus, English in Bukovyna, which at that time was a part of AustriaHungary, was taught via the German language. We contemplated on the methodological aspects of teaching English in the Bukovynian schools for girls and the techniques applied for the development of English pronunciation, reading, speaking, writing and translation skills. Thus, the peculiarities of the principles of realization of grammar-translation and text-translation methods are revealed and the process of transition of the above-mentioned methods to the direct method of teaching English is illustrated in the textbooks being analyzed.
\end{abstract}

Keywords: Bukovyna; female school; textbook; English language teaching; methodology; grammar reference; reader.

Introduction. The English language teaching (ELT) methodology has gained significant development in the XXI century, the time of globalization and expanding international relations. There emerged a need to find new methods, technologies and effective techniques of teaching foreign languages that would ensure quick and thorough mastering the English language, which serves as a means of international communication. Little attention has been paid to the history of the English language teaching methodology in Ukraine in general and in Bukovyna in particular. This knowledge would make it possible to use the invaluable experience of the past and to apply it efficiently to the needs of our time.

The history of teaching methods of foreign languages, the problems of structure and content of textbooks of the past have gained the interest of such methodologists as A. A. Miroliubov (studied the history of foreign language teaching methodology in Russia) and B. I. Labinska (highlighted the establishment and development of foreign languages teaching methods in the Western Ukraine in the second half of the XIX - early XX century). English textbooks, used on the territory of Bukovyna in 1900-1918 have not been the subject of a separate scientific research, that is why the objective of this article is to analyze the structure and content of textbooks in English in the above mentioned period, group them according to common characteristics, contemplate on the criteria for the analysis, define the method of teaching English in the outlined historical period and peculiarities of its use in the Bukovynian female schools. Bukovyna, which was a part of the Austro-Hungarian Empire at that time, has been chosen the object of the study. This region, as a result of historical processes and because of its geographical location, has become a multinational and multilingual territory, which makes our study interesting and new from a scientific point of view.

The study of the content and structure of modern textbooks have been the subject of the research of such scientists as A. R. Arutyunova, N. P. Basai, V. P. Bezpalko, O. B. Bihych, I. L. Bim, N. F. Borysko, G. Widdowson, C. Willing, N. D. Halskova, L. V. Kalinina, A. A. Kolominova, S. Y. Nikolaeva, V. G. Redko, V. M. Plakhotnik, S. V. Roman, N. K. Skliarenko, who investigated the problems of content, structure, criteria and methods of evaluation of textbooks in foreign languages. In particular, N. F. Borysko notes that a textbook plays a dominant role in the FL learning and has a number of important functions, including basic - modeling, training and management; additional - informing, compensating, motivating, individualization, profession, controlling, organizational-planning; metafunctions - adaptive optimizing and diagnostic (Borysko, 1999, p. 22-25). Let us try to find out whether the textbooks in English used in Bukovyna in schools for girls in the early twentieth century performed the above-mentioned functions. 
Methods. To implement the task we used general scientific and empirical research methods. Analysis, synthesis, induction, deduction, abstraction, comparison and synthesis were used for the study of literature sources. The critical analysis of educational documents, curricula and textbooks in English, approved by the Ministry of Education and Religion of Austria-Hungary in the between 1900 and 1918, has been made. We have studied the funds of the State Archive of Chernivtsi region, including F. 211, 233, 237, 320, to track the changes which took place in the education of Bukovyna and their impact on the methods of teaching English. The hermeneutic method was used in an attempt to preserve the authentic verbatim content of the translation and interpretation exactly as it was understood by the contemporary authors, using the conceptual categories apparatus of those times and keeping the original language in the titles of the textbooks.

The practical value of the research lies in presenting new documents and literature which has not been used in scientific pursuits before and in the contribution into the development of the regional pedagogical and historical education. The results of the research can be included in theoretical courses (both optional and obligatory) for the students of the departments of pedagogy, at teacher-training institutions of higher qualification levels.

Results. Such foreign languages as German, French, Polish, and Italian were taught in Bukovyna in the late XIX - early XX century. The English language teaching in this region started relatively late, but the development of its methods was dynamic, as reflected in the textbooks of the time.

Four types of methodological guidelines by which we can analyze a particular textbook were generally identified: formal, functional, structural and subjective. Formal criteria presuppose clarification of the bibliographic data of a textbook, its design and complexity. Regarding the design, ergonomics are important indicators, namely the quality of printing, design and readability. According to functional criteria, one should take into account age, physiological, mental and individual psychological characteristics of students. The structural characteristics include the reasonable title of a textbook, a distinct representation of the content, clear structuring (oriented on achieving consistency and concentricity of the supply of language and speech material from lesson to lesson), rational organization of the procedural aspects of the learning content, focus on personality-oriented model of the educational process. The subjective criterion is also important as it defines the personal attitude of students and teachers to the particular textbook.

In our analysis of English textbooks used in Bukovyna in the late XIX - early XX century, we can be guided by the above-mentioned criteria developed by outstanding pedagogues of today. However, not all of these characteristics may be relevant for us because the investigation is limited to a certain historical framework. For example, it seems impossible to consider the subjective criteria, as it involves a survey of students and teachers. These data have not been found in the discovered historical documents. Therefore, it is necessary to take into account the peculiarities of the historical period and try to apply the achievements of the modern science of methodology.

It should be noted that the end of the XIX - early XX century is characterized by turning changes in the education system of Austria-Hungary in general and in ELT methodology in particular. Modern methodologist B. I. Labinska notes that the so-called Reform movement, which was attaining popularity in Europe at that time, had an impact on the development of FLT methodology in Bukovyna. Translation teaching methods lost their relevance and gave way to new progressive methods, such as the direct method of FL teaching. The process of changes was reflected on many levels - in educational documents, new school curricula and programs and, of course, in FL textbooks (Labinska, 2013, p. 86-87).

Let us analyze the following English textbooks, used in schools for girls: L. Kellner, J. Baudisch "Sonnenburgs Grammatik der Englischen Sprache", J. Ellinger, P. Butler "Lehrbuch der Englischen Sprache (A Short English Syntax and Exercises)", W. Swoboda "Schulgrammatik der modernen englischen Sprache mit besonderer Berücksichtigung der Geschäftssprache", W. Swoboda "Lehrbuch der englischen Sprache für Mädchenlyzeen und andere höhere Mädchenschulen" 1. Teil Elementarbuch, Teil II A First English Reader. This list corresponds to the chronology of the use of textbooks in the above mentioned institutions. All our books are divided into 3 groups: 
and exercises));

- grammar reference books (containing mostly grammatical material (explanations

- textbooks (educational books that provide lexical topics and grammar, as well as texts for reading comprehension);

- readers (consisting of samples of authentic texts placed on the principle "from simple to complex", designed for reading and contain pre- and after-reading tasks).

First of all, it should be noted that all textbooks were listed in the corresponding school programs and curricula and approved by the Ministry of Education and Religion of Austria-Hungary (Jahresbericht des öffentlichen Städtischen Mädchen-Lyzeums in Czernowitz, 1902). Another peculiarity is that the textbooks language was German, as all of them were published in Vienna by German-speaking authors.

Thus, the first textbook under analysis will be "Sonnenburgs Grammatik der Englischen Sprache" by Julius Baudish and Leon Kellner, published in 1895. The textbook belongs to a group of grammar reference books. Structurally, the course book consists of four sections: pronunciation, morphology, syntax and exercises. The first chapter introduces the phonetics of English. In the beginning the English alphabet is given, further, the pronunciation of vowels in various types of syllables, sounding of consonants and stress are explained. The second section consists of the presentation of grammatical material which is given schematically in the form of tables, without long explanations. Among the topics, one can get acquainted with the noun, plural formation, adjectives and their degrees of comparison, articles, tense forms of verbs and so on. There are many examples that are immediately translated into German. This textbook assumes the leading role of the teacher, whose task is to explain all the difficult grammatical phenomena, while the textbook serves as an auxiliary aid. It should be noted that the sentences that illustrate a particular topic, are unrelated by content, so the given textbook serves only for learning grammar.

Note that the exercises in the modern sense of the term are absent in the Baudish and Kellner's textbook. Although the section is called "Übungsbuch" (exercise book), here we find only a list of words or sentences in English (mostly proverbs), also it could often be expressions on religious topics. The instructions for the so-called exercises are not given, so we can only assume that it was necessary to read these samples. Starting with the 14th lecture one can find dialogues that are of scientific nature, including astronomy, physics and others. Further, we see the texts of the cognitive content (e.g. coal, ice, animals, insects, leather, money, rain and snow, festivals), for which the questions are offered. In the last lectures, the texts are quite complex and lengthy, mostly fragments from the history of Britain. At the end we find the translation of words, which were used in the lectures, exercises for translation from German into English and an English-German dictionary. The illustrations in the book are missing, which, in our opinion, is a negative factor, and it does not evoke the interest in students and facilitate their better perception of the learning material. The textbook "Sonnenburgs Grammatik der Englischen Sprache" was not the main means of learning English in schools for girls, because the program in English in the Girls' Lyceum of 1901/1902 academic year, gives a clear objective of the learning: skills in speaking and writing in everyday situations; understanding simple prose and poetry; the knowledge of morphology and syntax; familiarity with the outstanding works of literature starting with Shakespeare (Jahresbericht, 1902). We have reason to believe that this textbook could not serve for the full achievement of the above-stated objectives of teaching English, because using it one could only form grammar skills and build skills in reading as there were no exercises on the development of dialogue and monologue speech and writing.

Let us move to the next English textbook "Lehrbuch der Englischen Sprache (A Short English Syntax and Exercises)", composed by Dr. Johann Ellinger and A. J. Perceival Butler and published in 1907. The front page of the textbook says that it was appointed for the girls' lyceums and other female schools. The textbook consists of two parts: theoretical and practical. The first part provides information about such grammatical phenomena as word order, articles, nouns, adjectives, pronouns, numerals, verbs, infinitives, gerunds and participles. The explanation was given in German, though English examples are not translated into German. It is interesting that at the bottom of each page there is a horizontal line, footnote, and below we can see the same explanation in English. The material is easy to understand, sentences are short, simple. If a student knew German and had an idea of its 
grammar, it was easy to understand the material from the textbook. The second part contains exercises for reading in English with highlighted grammatical phenomena which were given in the lectures and the chapter, where one could read the theory, is specified. After reading, there are exercises for translation from German into English. At the end of the textbook one can find English-German and German-English dictionary and a glossary for each paragraph.

So, we can assume that this textbook was written by the supporters of the translation methods that took literal translation and grammar as the basis of learning a foreign language (grammartranslation method); and encouraged to learn a foreign language with the help of the original texts and their translation into students' native language (textual-translation method).

The textbook by Wilhelm Swoboda "Schulgrammatik der modernen englischen Sprache mit besonderer Berücksichtigung der Geschäftssprache" was published in 1906. We have managed to find a few textbooks by this author in the scientific library of Yuriy Fedkovych Chernivtsi National University. These books were widely used in the schools of Bukovyna in the end of the XIX - at the beginning of the XX centuries. The given textbook is clearly structured, it consists of 297 chapters. The first 11 chapters represent the course in phonetics, where the author describes vowels and consonants, intonation, explains the reading rules (in German).

The second part of the textbook contains grammatical material, which is also presented in the narrative form of German, but the examples are not translated from English. In this textbook, which, like the previous two, belongs to the group of grammar references, one can find exercises that are different from those which we saw in Baudish, Kellner and Ellinger, Butler. First, the author gives a task to each exercise in English. Secondly, these are not just exercises for reading and translation, here the students have to explain a particular phenomenon in a certain grammatical sentence. For example:

"How do you account for (or how do you explain) the position of the adverb "never" in the sentence "Gideon never spent a penny".

Next, the author gives an example of the answers to this question: "Contrary to German use adverbs are often placed (put) before the verb in English. In the above example the statement "Gideon never spent ..." would be incomplete without its object "a penny". The word "never", therefore, does not modify (qualify) the verb "spent" alone but also its object the sense of the sentence being "that it was never that Gideon spent a penny" ..." (Swoboda, 1906, p. 21).

In our opinion, the textbook is overloaded with grammatical explanations which are provided synthetically; excessive theorizing of the learning does not facilitate the formation of practical skills, including speaking and, as mentioned above, in this period there took place changes regarding the aim of teaching English and the focus was shifted towards the mastery of spoken language and development of communication skills, information perception and transmission. In the book we didn't find any illustrations. The last chapter is devoted to the punctuation marks. Here we can see the tasks to put commas in the right places, which is also new to us. We assume that this textbook was designed for future teachers of English who had to learn to explain grammar very well.

Another two textbooks by W. Swoboda "Lehrbuch der englischen Sprache für Mädchenlyzeen und andere höhere Mädchenschulen 1. Teil Elementarbuch", and "Teil II A First English Reader" deserve our attention. The first part "Elementarbuch" (1908) belongs to the group of textbooks, and the second part (1914) is a reader.

Swoboda's textbook received the permission from the Ministry of Education and Religion of Austria-Hungary, which is stated on the first page. The book, published in 1908, consists of three major parts ("School", "Home", "Nature"), which are divided into sections: "Our Class-Room", "Speaking and Reading", "Writing", "Conduct" "Arithmetic", "Food", "Houses", "Family", "Furniture. Dress", "The Human Body", "Occupations", "Needlework", "Forest". The sections, in turn, are divided into lessons (43).

The first six lessons is a phonetic course, which consists of an explanation of the sounds, their types, syllables, stress, intonation, reading rules. At the beginning of each lesson a poem in the form of phonetic characters with accents is presented. The rules of reading in various types of syllables and letter combinations are described. At the end of the fifth lesson the exercises for reading and dictations are given. 
Starting from the sixth lesson the author introduces grammatical material which is presented through examples (sentences) with grammatical phenomena, studied in each lesson, highlighted with bold colors. After examples, the explanation takes place in the form of charts and tables. In some cases, there is a grammatical interpretation of the rules in German. It should be noted that the presentation of the grammatical material is small in size, consisting mainly of short sentences which are easy for perception. In this case, we have reasons to believe that the author tried to adhere to the principles of the direct method in the presentation of the grammatical material. He applied the inductive method, which involved providing students with opportunities to deduce rules from examples. This strengthened the role of observation and, according to the representatives of the above-mentioned method, helped better mastering of grammar.

At the end of the lesson one can see exercises, for example:

"Exercises:

1. Answer the following questions: Where are you? How is our classroom? Where is the door? What is in the sidewall? Is the door open? Where are the windows? What objects are paced in the room? Where is the teacher's table and chair? What is on the end-wall? What is hanging on the map-stand? With what are walls decorated? Where are your cloaks? What is placed on the door? What is hanging down from the ceiling? When is the gas lighted?

2. What is the plural of: room, door, wall, cloak, class, table, chair, place, desk, exercise, hatrack, teacher.

3. Write out the plurals and put them in three columns, thus:

$s|z| i z$

4. Dictation. It is dark. The gas is lighted because it is dark. We put on our cloaks. Your hat is new. Don't put it in. It is raining. It is a bad day. There is the house. We are at school. Now we are in our class-room. We shut the door. There is your seat. Put down your books. Sit down" (Swoboda, 1908, p. 14).

As you can see from the example, first go questions on the topic (in this case it is "Our ClassRoom"), which students had to answer orally. It developed their speaking skills. Further, there are grammar tasks and in the end - a dictation. It should be noted that the instructions are written in English, so the author tried to maximize the use of the language being studied. The exercises are increasing in number and become more complex with each lesson.

By the tenth lesson, the author gives the rules of pronunciation and spelling with numerous examples. The presence of many dialogues that reflect everyday conversations shows that the author tried to meets the requirements of the developers of the direct method.

In the book there are texts of didactic and moralistic character. For example, the themes "Don't be careless and untidy", "Don't be late for school"; in some lessons it is explained how to behave at the table. Thus, the textbook fulfills not only learning, but also educational function.

It is worth mentioning that the 21-st lesson is a review in which the author tells which topics were covered at the previous lessons. For instance: "We have had twenty lessons as yet. The first five lessons were devoted to a course of spelling and pronunciation. The sixth lesson was about our classroom, the seventh about an English lesson. In the eighth lesson we were addressed by our English reading-book; the ninth was a practical reading lesson..." (Swoboda, 1908, p.50). There take place the complication of the study material, the increase in the number of texts. We can read poems, stories about holidays in Britain and the British way of life. In the lessons, the vocabulary is not presented separately, we can see only texts and dialogues, but the translation of words into German is found at the end of the course book. The presence of synonyms and antonyms of certain lexical units is very important, that served to enrich the vocabulary of students. Also, worthy of attention are examples of advertisements from English newspapers and samples of correspondence that proves the development of writing skills and the practical value of the textbook. Note that after translation of words there are also exercises for translation from German to English. Also, the author added the English-German dictionary and illustrations of British coins.

Thus, it can be asserted that in this textbook the principles of the direct method were implemented, namely the creation of the language environment, limiting the use of the native language of the student and translation; inductive explanations of grammatical material; the use of a 
large number of exercises on the development of speaking (questions and answers); paying attention to the pronunciation; using synonyms and antonyms to enrich students' vocabulary. However, the author emphasizes the educational and cognitive functions of teaching foreign languages, which is illustrated by the different types of texts and pictures, and underlines the practical application of knowledge acquired by students.

The second part of this textbook, a reader, was reprinted in 1914. We managed to find only the second edition, so we cannot trace the changes that were made to the textbook. First of all, it should be noted that this anthology was written entirely in English. Structurally the textbook is divided into 5 parts in which texts are grouped thematically: 1) general information about the United Kingdom; 2) the main events in the history of England; 3) biographies of famous people; 4) fairy tales and short stories. Here we see the excerpts of works by Lewis Carroll, Robert Browning, Rudyard Kipling, Alfred Tennyson. The book is full of a great number of illustrations depicting the attractions of Britain, its architectural monuments, universities, scenic landscapes, well-known figures in the English history and maps of London and the United Kingdom. All tasks and explanations are given in English. The exercises are mainly reproductive, conventionally communicative. However, there are some exercises of communicative nature, like to show a particular town on the map, to explain certain lines, to determine the advantages and disadvantages of some facts. Example: 'Questions and answers. 1. What is meant by the 'central position' of the British Isles? - 2. What advantages does this position afford to their inhabitants a) with regard to the Continent of Europe, and $b$ ) with regard to the other parts of the world? " (Swoboda, 1914, p. 3). The author also offers exercises for the development of writing skills: writing compositionsdescriptions using prompts. For example: "Compositions: 1. Give a short description of an Oxford college (from the picture). Hint: Chapel, Hall, Library, lodging-houses, walks and grounds; Gothic style. 2. Describe the dress of an Eton boy (silk hat, jacket, turn-down collar, light trousers) (Swoboda, 1914, p. 7)"'. After texts one can see synonyms to the keywords, which are met in the texts, set expressions, as well as some rules of word-building:

"Synonyms. Border - limit (generally speaking) - confines (borderland) - frontier (merely political).

Rock - cliff - crag (Swoboda W., 1914, p. 41)".

This reader is a sample of progressive changes that were taking place in the methodology of teaching foreign languages in the early twentieth century. Here we can feel the influence of the Reform movement, whose representatives introduced the direct method of teaching foreign languages in Europe. This is evidenced by avoiding the use of the mother tongue in the textbook, the presence of authentic texts, enriching vocabulary by learning synonyms and phraseology, word formation rules.

Discussion and conclusions. Having reviewed the main textbooks used in female schools of Bukovyna, let us try to analyze them according to the criteria that we mentioned at the beginning. So, due to the formal criterion, in our opinion, the textbooks by W. Swoboda, published in 1908 and 1914 , meet the requirements best of all, because they have a nice appearance, high quality of printing performance, convenient design and are readable. Other textbooks are of a slightly lower quality, they mostly have small print and the design was not encouraging pupils to learn. The analyzed textbooks partially meet the functional criteria, which take into account age, physiological and psychological characteristics of students With regard to the structural characteristics, all the textbooks of the period under study were complied with the requirements of the curriculum approved by the Ministry of Education and Religion of Austria-Hungary. Language and speech material is presented successively and concentrically, in a clear and understandable manner. The textbooks of that time were the main means of learning and performed most of the functions assigned to them, to some extent contributed to the achievement of the objectives specified in the curriculum, favored the development of skills in phonetics, grammar, vocabulary, partially in speaking and writing, as well as in translation. Here we can spot the evolution in the aim of teaching English in Bukovyna. At the end of the XIX century, the objectives were mainly to teach children to read texts and to understand grammar; little attention was paid to the development of speaking skills. The textbooks' analysis proves the use of grammar-translation and text-translation methods at schools. The beginning of the XX century 
brought advanced changes in the European educational system which had its influence on the development of English teaching methods in Bukovyna, which was a part of Europe at that time. All these changes were reflected in the textbooks, published in 1908-1915. Here we can see conversational topics, dialogues, manifold exercises, aimed at the practical use of grammar. So, the accent was shifted to the cultivation of communication skills which was dictated by the needs of the epoch. The innovations introduced in the structure and content of the new textbooks had a purpose to correspond to the new requirements of the society and to implement the principles of the direct method of teaching English. We believe that this method is a valuable achievement of the methodology as a pedagogical science. It still has its supporters nowadays and some of its ideas and provisions can be used while teaching English in modern Ukrainian schools and in the textbooks of English.

The perspective of the further research can be an analysis of the content and structure of English textbooks in Bukovyna in the second half of the XIX century aiming at deeper understanding of the origin and peculiarities of the development of the methodology of teaching English in the Bukovynian region.

\section{References:}

Baudisch, J. \& Kellner, L. (1895). Sonnenburg Grammatik der englischen Sprache nebst methodischen Übungsbuche für österreichische Schulen [Sonnenburg's grammar of the English language with methodological exercises for Austrian schools] (2 ${ }^{\text {nd }}$ ed.). Berlin, Germany: Springer; Vienna, Austria: Gerold.

http://dx.doi.org/10.1007/978-3-642-49885-5

Borysko, N. (1999). The criteria of the analysis and evaluation of textbooks and teaching-methodological complexes in foreign languages. Inozemni movy [Foreign languages], 1, p. 22-25.

Ellinger, J. \& Perceival Butler, A. J. (1907). Lehrbuch der englischen Sprache [English Textbook]: A short English Syntax and exercises with an English-German and a German-English glossary. Vienna, Austria.

Jahresbericht des öffentlichen Städtischen Mädchen-Lyzeums in Czernowitz. Erstattet am Schlusse des vierten Schuljahres 1901/1902 vom Direktor Dr. Josef Frank. Im Selbstvertrage der Anstalt. [Program of the Municipal Gils' Lyceum in Chernivtsi at the end of the 4th school-year 1901/1902]. (1903). Chernivtsi: Czernowitzer Buchdruckerei-Gesellschaft.

Labinska, B. (2013). Istorychni narysy z metodyky navchannia inozemnykh mov na zakhidnoukrayinskykh zemliakh (druga polovyna XIX-persha polovyna XX st.) [Historical Essays on the methodology of teaching foreign languages in the Western Ukrainian lands (the second half of the XIX-the first half of the XX century)]. Kyiv, Ukraine: KNLU.

Labinska, B. (2015). A lesson of foreign languages: German at Ukrainian schools of Bukovyna and Galicia in the period of 1867-1939. In M. Winkler (Ed.), The Habsburg coinage of language and education in Bukovyna 1848-19181940 Conference (pp. 163-173). Regensburg: Friedrich Pustet.

Miroliubov, A. (2002). Istoriya otiechestvennoi metodiki obucheniya inostrannym yazykam [The history of the Russian methodology of teaching foreign languages]. Moscow, Russia: Stupieni; Infa-M.

Swoboda, W. (1914). Lehrbuch der englischen Sprache Sprache für Mädchenlyzeen und andere höhere Mädchenschulen. T. II: A First English Reader [English Textbook textbook for girls' lyceums and other female schools. Part II: A First English Reader]. Vienna, Austria: Franz Deutiche.

Swoboda, W. (1906) Schulgrammatik der modernen englischen Sprache mit besonderer Berücksichtigung der Geschäftssprache [A school grammar of the English language with special emphasis on professional language]. Wien, Austria: Franz Deutiche.

Swoboda, W. (1908). Lehrbuch der englischen Sprache für Mädchenlyzeen und andere höhere Mädchenschulen. T. I: Elementarbuch [English textbook for girls' lyceums and other female schools. Part 1: elementary book] ( $2^{\text {nd }}$ ed). Vienna, Austria: Franz Deutiche.

Swoboda, W. (1915). Lehrbuch der englischen Sprache für Mädchenlyzeen und andere höhere Mädchenschulen. T. I: An English Primer [English textbook for girls' lyceums and other female schools. Part 1: An English Primer] ( $3^{\text {rd }}$ ed.). Vienna, Austria: Franz Deutiche. 